\title{
Consumer behavior-focused training in retailing education: Too much of a good thing?
}

\author{
Hidajat Hendarsjah * (D), Haryanto Haryanto \\ Universitas Sebelas Maret. \\ * Corresponding Author. Email: h.hendarsjah@staff.uns.ac.id
}

\section{ARTICLE INFO}

\section{Article History}

Received:

7 April 2021;

Revised:

18 May 2021;

Accepted:

20 August 2021;

Available online:

2 November 2021

\section{Keywords}

Retailing education;

Retailing decisions

\begin{abstract}
Consumer behavior training extensively delivered in the tertiary vocational school of business had been expected to equip students with deep knowledge in marketing and sales. This was true when students were dealing with general business environments, but it was dubious when it was implemented in a certain field of business, such as retail business. Retail business, predictably, had a unique characteristic in its business decisions. Students in the Marketing Program of a tertiary vocational school in their final year were the object of the study. Employing the non-parametric tools to assess student knowledge in consumer behavior and its association with retailing decisions mastery, it was found that student mastery in consumer behavior did not associate with better knowledge in other five retail business decisions (determining the composition of goods, spotting locations, pricing, profit strategy, and store management). The article also provided a brief explanation that specific knowledge in consumer behavior did not always in line with the required knowledge in the retail business. It was also suggested that to elaborate whether one particular knowledge of business practices had a valuable feature was, first, by determining its overall decisions relating to it. Then, the second, establishing a series of analyses to assess whether the decisions have any relations with the college's courses or training of a field of study. Comprehension of the process might help the vocational school to equip students with the right required knowledge and skills for a certain field of business.
\end{abstract}

This is an open access article under the CC-BY-SA license.

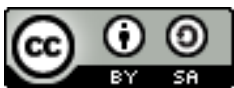

\section{How to cite:}

Hendarsjah, H., \& Haryanto, H. (2021). Consumer behavior-focused training in retailing education: Too much of a good thing?. Jurnal Pendidikan Vokasi, 11(2), 125-132.

https://doi.org/10.21831/jpv.v11i2.39928

\section{INTRODUCTION}

With more than 250 million people, of which are buoyant private consumers, Indonesia is recognized as the main driver of Indonesia's robust economic growth (Baur \& Wee, 2015; Yuningsih, 2019). The high growth in consumer spending in grocery, more than $45 \%$ within the last five years (Nielsen Indonesia, 2018), means Indonesia has a positive financial sentiment in the retail business. According to the Reynolds (2019), retail trade-in Indonesia had increased $0.7 \%$ Year on Year in September 2019, following a 1.1\% rise the previous month, supported by sales of food, beverages, and tobacco (1.4\% vs. $0.3 \%$ in August) and household equipment (11.1\% vs. $8.3 \%$ in August). Further, in the last quarter of 2019, Indonesia's consumer spending was above 1,500 trillion Rupiah, the highest value since 2010. All these facts imply that the buying behavior of Indonesian retail 
consumers is very attractive to foster retail business. Various retail formats respond to this to cultivate the huge opportunity of the business.

Both major global and local retailers compete to service Indonesia consumers, from Metro, Sogo, Carrefour, McDonald's, and Pizza Hut, to Ace Hardware, Informa, Gramedia, and Rumah Makan Sederhana. The global and local retailers (even in the traditional format, like the street vendors and sellers in the wet market) are consistently competing for the retail market share. In recent years, retailing in digital format has also entered the Indonesian market. The OLX, Booking.com, Shopee, Traveloka, JD.ID, Tokopedia, and Gojek groups are among the most aggressive digital retailers. Buying a house, a train ticket, or even ordering favorite foods is even easier for the consumers.

The lucrative opportunities of the retail business lure many vocational schools in tertiary level (i.e. vocational colleges) to engage with the dynamics of the Indonesia retail business. numerous undergraduate programs are offering retailing management skills to their students. The schools offer various training series on the specific sets of retailing management decisions (Cox \& Brittain, 2004; Dunne et al., 2013; Levy et al., 2019; Nielsen et al., 2012; Schroeder, 2002). Our scant interviews with students of a tertiary vocational school revealed that they had basic and essential knowledge in defining consumer behavior (as discussed in general marketing management courses). The students also implied that marketing management's consumer behavior perspective had identical features for every business. At this point, we doubted if it implied a necessary-and-sufficient footing when coping with some decisions in the retail business.

Trends in the world of retailing are not simply triggered by the shifting preference of consumers (Chatterjee \& Kumar, 2017b, 2017a; Grewal et al., 2018). Technology advancement is also the important driver for shaping the retail formats as well as driving the shift preference of consumer behavior. In fact, the two mentioned drivers may affect one to another to form the trends in retailing. The assumption implies the possibility that current knowledge in consumer behavior is not the only focal point to foresee future trends in retailing as well as to deliver trends in retailing education.

Following the work of Grewal et al. (2018), by tracing back the topics covered in Retailing Management text book co-authored by Levy and Weitz from 1992 until 2018 or ten years editions, it was shown that topics covered in retailing education had been advancing from agile delivery system, television shopping, electronic retailing, multichannel retailing, Geographic Information System (GIS) technology, and customer relationship management systems in the first five editions to radio frequency ID, website design, in-store kiosk, digital signage, social media, mobile retailing, big data, and retailing analytics, omnichannel retailing, and robotics in the sixth to tenth editions. The study portrays that both retailers (when choosing the appropriate technologies to engage their customers) and retailing (through technology advancement) are in "co-influencing" mode in shaping the future trends of retailing.

Complementing the perspective, another study has a slightly different perspective when predicting the future trends in retailing, it focuses on consumers' needs to drive their purchasing behaviors (Grewal et al., 2017). The study focuses on five facets in understanding managing the consumer behavior shifts; they are technology and tools to facilitate decision making, visual display and merchandise offer decisions, big data collection and usage, analytics and profitability, and consumption and engagement, implying that retailers may choose various technologies to embrace their customers. Although the two studies seemingly explore more on the shifts and trends in consumer behavior, their findings imply that knowledge in pure human behavior when consuming goods and services, as it is crafted in Consumer Behavior courses, is no longer the single option in defining the future trends in retailing.

In line with the above-mentioned perspectives, the advancement of retailing management can be viewed as a close relationship between the macroenvironment and the microenvironment (Levy et al., 2019). The macroenvironment includes technological, social, ethical, legal, and political factors on retailing, whereas the interaction between the retailer's competitors and customers is deemed as the microenvironment (Levy et al., 2019). The latest perspective implies that there are a series of decisions when dealing with the retailing environment. 
Based on a scant literature review, there is a specific managerial decision-making process in dealing with a retail business. They are: 1.) Understanding and directing the consumer buying behavior; 2.) Setting financial objectives; 3.) Determining merchandise assortment; 4.) Spotting locations; 5.) Pricing strategy, and 6.) Store management (Levy et al., 2019; Schroeder, 2002). How do the six decisions have something in common with the two previously mentioned studies? (Grewal et al., 2017, 2018) Table 1 summarizes the implied decision grouping in retailing management, with reference to the six retailing decisions. As presented in Table 1, for example, by looking at the first retailing decision feature of Grewal et al. (2017) study (see column 3 of the Table 1), "Technology and Tools to Facilitate Decision Making", it comprises and is closely related with four retailing decisions as coined by Schroeder (2002) and Levy et al. (2019); understanding and directing consumer buying behavior, setting a financial objective, determining merchandise assortment, and pricing strategy. Similarly, all the retailing decisions of the two studies Grewal et al. (2017) and Grewal et al. (2018) can also be justified into the six retailing decisions.

Table 1. The Implied Decision in Retailing

\begin{tabular}{|c|c|c|}
\hline $\begin{array}{l}\text { Retailing decision based on consumer } \\
\text { preference shift and technology } \\
\text { advancement (Grewal et al., 2018) (1) }\end{array}$ & $\begin{array}{l}\text { Grouping on retailing decision } \\
\text { (Levy et al., 2019; Schroeder, } \\
\text { 2002) (2) }\end{array}$ & $\begin{array}{l}\text { Retailing decision based on the } \\
\text { consumer preference shift (Grewal } \\
\text { et al., 2017) (3) }\end{array}$ \\
\hline 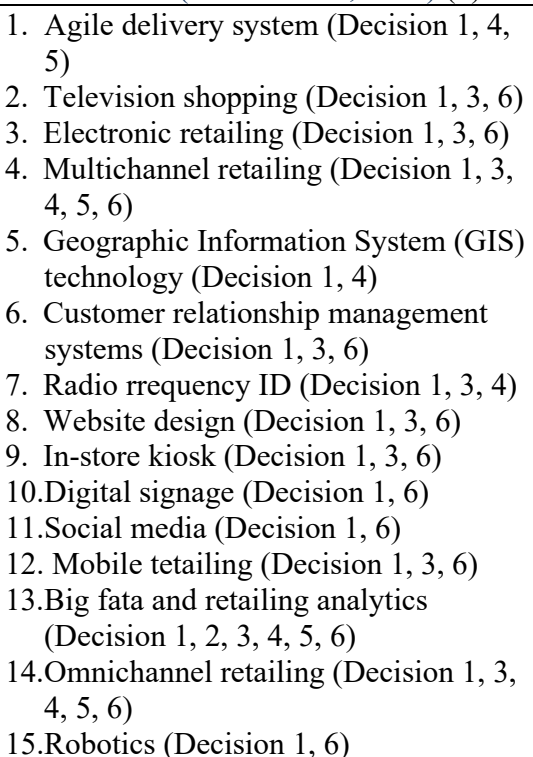 & $\begin{array}{l}\text { Decision 1: Understanding and } \\
\text { directing the consumer buying } \\
\text { behavior } \\
\text { Decision 2: Setting financial } \\
\text { objective } \\
\text { Decision 3: Determining } \\
\text { merchandise assortment } \\
\text { Decision 4: Spotting locations } \\
\text { Decision 5: Pricing strategy } \\
\text { Decision 6: Store management }\end{array}$ & $\begin{array}{l}\text { 1. Technology and tools to } \\
\text { facilitate decision making } \\
\text { (Decision } 1,2,3,5 \text { ) } \\
\text { 2. Visual display and merchandise } \\
\text { offer decisions (Decision } 1,3 \text {, } \\
\text { 6), } \\
\text { 3. Big Data Collection and Usage } \\
\text { (Decision } 1,2,5 \text { ), } \\
\text { 4. Analytics and profitability } \\
\text { (Decision } 1,2,3,4,5 \text { ), } \\
\text { 5. Consumption and engagement } \\
\text { (Decision } 1,3,6 \text { ) }\end{array}$ \\
\hline
\end{tabular}

Possibly the comprehension of consumer preference shift or the consumer behavior that seems to be sufficient for students in understanding the retailing management decisions should not be deemed as a strong assumption. The perspective is in line with the implied conclusion as presented in Table 1, that the advancement in retailing is not only triggered by the preference shift of consumers (see column 3 of the table); the technology advancement also has a critical role in shaping the retail business (see column 1 of the table). At this standpoint, there is a dubious thought that trends in retailing are formed mainly by the dynamic change of consumer behavior, implying that the mastery or comprehension in the consumer behavior can be associated with the mastery of the other retailing decisions. This article is aimed to test whether the student mastery in consumer behavior has a strong association with the mastery of the other five retailing decisions.

The six retailing decisions process (Levy et al., 2019; Schroeder, 2002) is best under-stood when presented in sequential order. It starts from understanding consumer buying behavior and is followed by setting a financial objective, determining merchandise assortment, spotting locations, pricing strategy, and store management, respectively. Purposedly, such an approach would also provide a brief explanation of what is needed to hold up each retailing decision. Describing the consumer buying behavior decision starts from the discussion about the buying process, beginning when customers recognize an unsatisfied need. Then to seek information about how to satisfy the 
need: what products might be useful and how they can be bought. In some situations, customers spend considerable time and effort selecting a retailer and evaluating the merchandise. In other situations, buying decisions are made automatically with little thought.

In sum, there are three types of customer decision making processes; they are extended problem solving (when risks are perceived as a consequence of purchasing the merchandise), limited problem solving (when the customers have had some prior experience with the product or service and their risk is moderate), and habitual decision making (when decisions aren't very important to customers and involve familiar merchandise they have bought in the past) (Levy et al., 2019). Thus, Retailing Decision 1 is understanding and directing the consumer buying behavior. The key indicator to sustaining the decision is how retailers define customer choices in goods and services (either by deep thinking, shallow thinking, or habitual bases).

From the retailer's perspective, once the financial objectives are set, the retailer starts determining what to buy (Nielsen et al., 2012). Financial plans start at the top of the retail organization and are broken down into categories, while buyers and merchandise planners develop their own plans and negotiate up the organization. Top management looks at the overall merchandising strategy. They set the merchandising direction for the company by defining the target market, establishing performance goals, and deciding which merchandise classification deserves more or less emphasis. The process of trading off variety, assortment, and backup stock of the merchandise is called assortment planning (Levy et al., 2019). In sum, Retailing Decision 2 is setting financial objectives along with its key indicator of how the merchandise assortment strategy meets the profit objective. Further, Retailing Decision 3 determines merchandise assortment, which has a key indicator of how retailers define their customer preference when establishing their merchandise assortment.

The next decision is to spot a retail location. In making store location decisions, retailers must examine the three-level decisions: region (it refers to the part of the country), trade area (a contiguous geographic area that accounts for the majority of a store's sales and customers), and specific site (Chopra \& Meindl, 2019; Levy et al., 2019). To accomplish these three location decisions sequentially, first, the retailers should look at the factors that affect the attractiveness of a particular region and trade area. Then the retailers examine what they look for on a particular site. Naturally, the most important factor in choosing a site is the potential amount of sales it can generate. The fourth retailing decision is all about spotting locations, and the related key indicator of the decision is how retailers define the attractiveness of retail locations based on regional trade area and specific site perspective.

In setting prices, under the cost-oriented method, the retail price is determined by adding a fixed percentage to the cost of the merchandise. With the demand-oriented method, prices are based on what customers expect or are willing to pay. With the competition-oriented method, prices are based on competitor's prices (Levy et al., 2019). Retailers need to consider costs, demand, and competition in setting the price. The cost-oriented method would be the starting point for setting a price. The competition-oriented method provides an outside check on the marketplace. The demandoriented method is then used for fine-tuning the strategy. Retailers are advised to start with a price based on costs and their profit goals, consider competition, and then perform tests to determine if it's the most profitable price (Levy et al., 2019). The possible-derived Retailing Decision 5 is pricing strategy, and it is sustained by the way retailers define cost and profit plans, competitions, and finetuning between the two.

The final decision in retailing is store management. It comprises human resource management and managing the store operations. Human resource management is important in retailing because employees play a major role in performing a critical business function. Retailers still rely on people to perform the basic retailing activities such as buying, displaying merchandise, and providing service to customers. One human resource management measure controlling people's performance is employee productivity; that is, the retailer's sales or profit is divided by the number of employees. Employee productivity can be improved by increasing sales generated by employees, reducing the number of employees, or both. While employee productivity is directly related to the retailer's shortterm profits, employee attitudes such as job satisfaction and commitment have important effects on customer satisfaction and subsequent long-term performance of the retailer. In addition to employee 
survey measures of these attitudes, a behavioral measure of these attitudes is employee turnover (Colquitt et al., 2019; Levy et al., 2019).

To manage the retail stores, the responsibilities of store managers are divided into four major categories: managing employees, controlling costs, managing merchandise, and providing customer service (Cox \& Brittain, 2004; Dunne et al., 2013; Levy et al., 2019; Schroeder, 2002). While an important objective of store managers is increasing the revenues generated by employees, managers also increase their stores' profits by reducing costs. The major costs are the compensation and benefits of employees. But store managers also need no control over maintenance, energy costs, and inventory loss due to shoplifting and employee theft (Levy et al., 2019). In general, the 6th Retailing Decision is store management. The key indicator to sustaining the decision is how retailers develop their perspectives in deploying people to manage the store.

The literature review on the above mentioned six major decisions in managing retail business implies that when students are exposed to the general marketing management or salesmanship courses, which equip students with deep knowledge on consumer buying behavior, we argue that it is hard to predict that they will automatically comprehend the other five decisions as each decision has unique complexity that needs various approach to cope with rather than a single perspective on consumer buying behavior or, in other words, the retailing decisions would not easily be managed just because of the deep knowledge in consumer buying decisions. The argument also refers to the various jobs performed in the retailing industry. Each job reflects the various and unique retailing decisions. The jobs perform an array of decisions processes to sustain the business.

\section{RESEARCH METHOD}

The sample of this research was final year students of an Indonesian state-owned vocational college majoring in Marketing Management. The sampling frame was fit for the research purpose, as: 1.) The final year students had learned all the marketing courses entirely; and 2.) They had gone through several marketing project assignments when attending the courses, thus consequently, they had been experiencing all marketing decisions delivered in the marketing courses at the school.

The data (it comprised of responses to the series of open questions) was collected when the students attended a full-day training in retailing management. A Series of questions covering the previously derived six decisions in retailing management (Levy et al., 2019; Schroeder, 2002) were distributed to those 58 participants (see the detailed questions in Appendices of this article). As the research employed nonparametric or population distribution-free techniques, such as a very small sample size, it implied that the nonparametric techniques do not have to follow the strict assumption to estimate the population (Israel, 2008). An expert panel of three members then evaluated and provided scores on the participants' responses.

The sample questions were "could you mention several merchandises to buy on a deepthinking basis, and why is it so" (consumer buying behavior), "What sort of menu do you offer if you were a restaurant owner" (determining merchandise assortment), "Which site do you think is better off if you have a car showroom" (site selection), "How do you manage a profit of a grocery store" (setting financial objectives), "What is your suggestion in determining staff composition in a retail toy store" (human resource management), "Could you mention the major problems when managing a grocery store" (managing store), and "what would you do when you set a merchandise price" (setting the price).

Firstly, the Chi-square test was employed to compare participants' best scores of the retailing decision frequencies against their expected frequencies (Israel, 2008). The null hypothesis was "there was no difference in the proportion of participants mastery in retailing decisions". This was to test whether participants tended to master certain retailing decisions. Next, the Mann-Whitney U test was utilized to evaluate whether participants with good mastery in a specific decision were also excelled to those of the other decisions (Israel, 2008). 


\section{RESULT AND DISCUSSION}

First, based on participants' scores (ranging from 0 to 100 scale), we assessed the proportion of participant mastery on each decision (Table 2). Table 2 shows the proportion of students that excelled in certain retailing decisions. As it was predicted, students had deeper knowledge in understanding consumer buying behavior (57\%) and pricing strategy (39\%). Twenty-nine students, out of 51, we're good at understanding consumer buying behavior.

A Chi-Square Test (Table 3) with each expected frequency was above 5 for more than $20 \%$ of the total expected frequency implied that it was suitable for further analysis (Israel, 2008). Further, the Chi-Square Test of the student mastery data (Table 2) revealed that $X^{2}(5,51)=11.07, p=<$ 0.05 , meaning that there was different mastery in retailing decisions for students, and it supported the assumption that knowledge in "understanding and directing the consumer buying behavior" (Decision 1) was the dominant mastery of the students. The finding implied that the school sample did not sufficiently equip students to deal with the retailing business.

Table 2. Participant Mastery in Retailing Decisions

\begin{tabular}{|c|c|c|c|c|c|c|}
\hline \multicolumn{6}{|c|}{ Decision } & \multirow{2}{*}{ Total } \\
\hline $1 * *$ & 2 & 3 & 4 & 5 & 6 & \\
\hline 29 & 0 & 1 & 20 & 1 & 0 & $51^{*}$ \\
\hline $57 \%$ & $0 \%$ & $2 \%$ & $39 \%$ & $2 \%$ & $0 \%$ & $100 \%$ \\
\hline
\end{tabular}

* 7 responses were incomplete, remaining the 51 responses

**Note:

Decision 1: understanding and directing the consumer buying behavior,

Decision 2: determining merchandise assortment

Decision 3: spotting locations

Decision 4: pricing strategy

Decision 5: store management

Decision 6: setting financial objective

Table 3. Chi-Square Data Set on The Student Mastery in Retailing Decision

\begin{tabular}{cccccc}
\hline Decision & $\mathrm{O}$ & $\mathrm{E}$ & $\mathrm{O}-\mathrm{E}$ & $(\mathrm{O}-\mathrm{E})^{2}$ & $(\mathrm{O}-\mathrm{E})^{2} / \mathrm{E}$ \\
\hline 1 & 29 & 8.5 & 20.5 & 420.25 & 49.44 \\
2 & 0 & 8.5 & -8.5 & 72.25 & 8.50 \\
3 & 1 & 8.5 & -7.5 & 56.25 & 6.62 \\
4 & 20 & 8.5 & 11.5 & 132.25 & 15.56 \\
5 & 1 & 8.5 & -7.5 & 56.25 & 6.62 \\
6 & 0 & 8.5 & -8.5 & 72.25 & 8.50 \\
& & & & 95.24 \\
\hline
\end{tabular}

The finding also indicated the possibility that Consumer Behavior content was the major emphasis when the school delivered marketing management courses. The question was whether the courses could equip students with sufficient knowledge if they were projected as retail professionals. To elaborate on the answer, we continued the analysis to test whether mastery in "understanding and directing the consumer buying behavior" implied mastery of the other five decisions. The MannWhitney U test was performed to test the null hypotheses: "mastery in Decision 1 implying identical performance in other five decisions". To do so, first, we divided participant scores into two groups; one of those with high scores in consumer behavior decisions and the rest of those with low scores.

Next, we compared other retail decision scores between the groups and analyzed whether participants with high scores in consumer behavior decisions also had high scores in other decisions (Table 4). It was noted that mean-centered scores identified the high and low scores groups in Decision 1. Thus, the low scorers would have values less than zero, whereas high scorers were those with values higher than zero. 
Table 4. Schedule to Compare Students' Other Mastery after Identified as High and Low Scorers in Decision 1

\begin{tabular}{cccc}
\hline Retailing Decisions & $\begin{array}{c}\text { Students with High } \\
\text { Scores in Decision 1 }\end{array}$ & $\begin{array}{c}\text { Students with Low } \\
\text { Scores in Decision 1 }\end{array}$ & Notes \\
\hline Decision 2 & Scores in Decision 2 & Scores in Decision 2 & Pair \#1 \\
Decision 3 & Scores in Decision 3 & Scores in Decision 3 & Pair \#2 \\
Decision 4 & Scores in Decision 4 & Scores in Decision 4 & Pair \#3 \\
Decision 5 & Scores in Decision 5 & Scores in Decision 5 & Pair \#4 \\
Decision 6 & Scores in Decision 6 & Scores in Decision 6 & Pair \#5 \\
\hline
\end{tabular}

The findings revealed that mastery in Decision 2 was statistically significantly higher when one showed mastery in Decision $1(\mathrm{U}=173, \mathrm{p}=0.031)$. This meant that mastery in determining merchandise assortment was higher for students with higher knowledge in consumer behavior. At the contrary, the Mann-Whitney U test also showed that the average level of Decision 3, Decision 4, Decision 5, and Decision 6 of participants were identical for students with high score in Decision 1 and those with low score in Decision 1: Decision 3: $(\mathrm{U}=199.5, \mathrm{p}=0.108)$; Decision 4: $(\mathrm{U}=211, \mathrm{p}$ $=0.138)$; Decision 5: $(U=268.5, p=0.974)$; Decision 6: $(U=252, p=0.424)$

Nevertheless, the findings showed that having high scores in consumer behavior decisions did not automatically have the mastery of setting a financial objective, spotting locations, pricing strategy, and performing store management. The findings partially supported our prediction that the mastery in Decision 1 did not mean comprehension in other retailing management decisions. This also implied that, in general, the nature of retailing management decisions was unique and had a broader perspective from just "understanding consumer buying behavior," as learned by students in Marketing Management courses.

The findings also implied that when vocational schools establish the knowledge and skills of their students to enter the retail industry, the curriculum should cover all retailing decisions. This was possibly true as retailing had higher relation with business operations decisions, not just coping with consumer behavior decisions, as implied by the above mentioned six retailing decisions (Chopra \& Meindl, 2019; Cox \& Brittain, 2004; Dunne et al., 2013; Levy et al., 2019; Schroeder, 2002).

\section{CONCLUSION}

The article provided a brief explanation on the perspective that specific knowledge in marketing management (i.e., consumer behavior), did not always in line with the required knowledge in a specific field of business (i.e., retail business). Based on the findings, to understand the phenomenon, whether one specific business knowledge had a valuable feature was, first, by determining its overall decisions. Then, second, a series of analyses should be established to assess whether the decisions have any relation with the college's courses or training of a field of study. Comprehension of the process might help the vocational school to equip students with the right required knowledge and skills for a certain field of business. The overall findings yield ideas for further research, that is, to test the association between other general functional management courses and the specific decisions in various fields of business. Such an approach would, expectedly, provide vocational schools with a comprehensive map in describing the association of each management course with various decisions in many fields of business.

\section{REFERENCES}

Baur, C., \& Wee, D. (2015). Manufacturing's next act. McKinsey \& Company. https://www.mckinsey.com/business-functions/operations/our-insights/manufacturings-nextact\#

Chatterjee, P., \& Kumar, A. (2017a). Consumer willingness to pay across retail channels. Journal of Retailing and Consumer Services, 34, 264-270. https://doi.org/10.1016/j.jretconser.2016.01.008 
Chatterjee, P., \& Kumar, A. (2017b). Teaching innovations in retailing education. Journal for Advancement of Marketing Education, 25, 1-2. http://www.mmaglobal.org/publications/JAME/JAME-Issues/JAME-2017-Vol25SpecialIssue/JAME-2017-Vol25-Special-Issue-Editors-Review-Chatterjee-Kumar-pp1-2.pdf

Chopra, S., \& Meindl, P. (2019). Supply chain management: Strategy, planning, and operation (7th ed.). Pearson Education.

Colquitt, J., LePine, J., \& Wesson, M. (2019). Organizational behavior: Improving performance and commitment in the workplace. McGraw-Hill Education.

Cox, R., \& Brittain, P. (2004). Retailing: An introduction (5th ed.). Prentice Hall.

Dunne, P. M., Lusch, R. F., \& Carver, J. R. (2013). Retailing (8th ed.). National Retail Federation.

Grewal, D., Motyka, S., \& Levy, M. (2018). The evolution and future of retailing and retailing education. Journal of Marketing Education, 40(1), 85-93. https://doi.org/10.1177/0273475318755838

Grewal, D., Roggeveen, A. L., \& Nordfält, J. (2017). The future of retailing. Journal of Retailing, 93(1), 1-6. https://doi.org/10.1016/j.jretai.2016.12.008

Israel, D. (2008). Data analysis in business research: A step-by-step nonparametric approach. SAGE Publications India. https://doi.org/10.4135/9788132108405

Levy, M., Weitz, B., \& Grewal, D. (2019). Retailing management (10th ed.). McGraw-Hill Education.

Nielsen, A. C., Karolefski, J., \& Heller, A. (2012). Consumer-centric category management: How to increase profits by managing categories based on consumer needs. Jogn Wiley \& Sons, Inc.

Reynolds, O. (2019). Indonesia: Retail sales are limp in September. Focus-Economics.Com. https:/www.focus-economics.com/countries/indonesia/news/retail/retail-sales-are-limp-inseptember

Schroeder, C. L. (2002). Specialty shop retailing: How to run your own store. John Wiley \& Sons, Ltd.

Yuningsih, N. (2019). Indonesia retail foods update. https://www.fas.usda.gov/data/indonesia-retailfoods-update- 0 